\title{
SYMBOLISM ASSOCIATED WITH LEADERSHIP IN SOUTH AFRICA: A SYSTEMS- PSYCHODYNAMIC PERSPECTIVE
}

Pieter Koortzen and Frans Cilliers; Pieter Koortzen@yahoo.com; Cllliefvn@unisa.ac.za. Department of industrial Psychology; University of South Africa

\begin{abstract}
This article focuses on the symbolic representations projected onto and into leaders in the South African organisational context. The aim is to explore the symbolic roles of leaders and the behavioural impact thereof. The research is conducted from a systems-psychodynamic perspective and a qualitative, explorative, social phenomenological study was conducted in an attempt to identify, analyse, describe and determine the impact of symbolic roles on leaders. The results seem to indicate that a number of symbolic roles, based on the diversity dimensions of race (black and white) and gender (male and female) and their different configurations, can be identified. The results are presented in the form of a number of working hypotheses on the impact of the symbolic roles on the conflict, identity, boundaries, authorisation, roles and tasks of leaders (CIBART).
\end{abstract}

Keywords: leadership, object relations, projection, psychodynamics, symbolism, Systems

\section{Introduction}

This research reports on consulting psychologists' experiences during executive coaching with organisational leaders, performed from the systems-psychodynamic consultancy stance. The focus is on the role of leadership in the organisation and how leaders unconsciously carry symbolic projections from and for their teams. The aim of this research was to create understanding about the symbolic representations projected onto and into leadership, by offering working hypotheses on the type of symbolic projections leaders presently carry for their teams and how that influences leaders' behaviour.

\section{Executive coaching}

Executive coaching is defined as a form of organisational consultation, a formal, on-going interpersonal relationship between (1) an individual or team having executive (including managerial and leadership) authority and responsibility in an organisation, and (2) a consultant who possesses in-depth knowledge of behaviour change and organisational functioning from various psychological perspectives and paradigms (Hall and Duval, 2004; Hillary, 2003; Huffington, Armstrong, Halton, Hoyle and Pooley, 2004; Lowman, 2002; Peltier, 2001; Schein, 2005; Sperry, 2004; Tonsing, 2003). 
The aim of executive coaching is to develop the organisation, its staff members and, specifically, the leadership of the system towards enhanced productivity, through intrapersonal, interpersonal and leadership growth in the role of the leader (Clutterbuck, 2003; Garman, Whiston and Zlatoper, 2000; Goldsmith, Lyons and Freas, 2000; Kilburg, 2000; King and Eaton, 1999; Meyer and Fourie, 2004; Peltier, 2001; Sperry, 2004).

The authors have been involved in executive coaching with leaders for some years. Generally, their aim is to fine-tune the leadership competencies of individuals in terms of job performance, and the maintenance and building of interpersonal relationships. In conducting role analyses with leaders and in clarifying their roles, the authors became aware that leaders are unconsciously influenced by their colleagues and teams. Specifically, a number of symbolic roles that leaders take up and/or are given by their colleagues and teams are coming to the fore. These roles seem to complicate the leadership role and de-authorise the incumbents.

\section{The systems-psychodynamic consultancy stance}

Because the studied behaviour lies 'below the surface5 (see Huffington et al, 2004), it was decided to conduct this study from the systems-psychodynamic consultancy stance. The conceptual origins of this perspective can be found in classic psychoanalysis, group relations theory and open systems theory (Miller, 1976; 1993). Consulting from this stance to leaders and teams has a primary task and this can be described as pushing the boundaries of awareness to better understand the deeper and covert meaning of organisational behaviour, including the challenges of management and leadership (Czander, 1993). This primary task is attended to during executive coaching, when leaders are offered opportunities to explore both conscious and unconscious processes, which includes an exploration of the symbolic roles they take up in a group (Huffington et al 2004).

In using a systems-psychodynamic perspective, it is assumed that the emotional task of the organisation is filled with chaos, a lack of control and difficult experiences such as competition, rivalry, jealousy, envy, hate, hostility and aggression which makes leadership difficult and relationships, relatedness and containment complex (French and Vince, 1999; Gould, Stapley and Stein, 2001). The specific nature of the perspective, as applicable to this research, can be summarised as follows (Koortzen and Cilliers, 2002; Neumann, Kellner and Dawson- Shepherd, 1997; Obholzer and Roberts, 1994):

DIt is a developmentally focused, psycho-educational stance, which is used to understand the deep and covert behaviour in the system, and is based on the five basic behavioural assumptions of dependency, fight/flight, pairing, oneness and we-ness (Bion, 1961; 1970; Lawrence, Bain and Gould, 1996; Turquet, 1974), 
$>$ It involves a socio-technical perspective which focuses on the interrelationships between the psychological (consisting of culture, group process, roles, role configurations and tasks) and organisational boundaries (such as the formal design and structures) (Colman and Bexton, 1975).

$>$ The coach's task involves interpreting and formulating working hypotheses about how the conscious (overt) and unconscious (covert) dynamics and behaviours (attitudes, beliefs, fantasies, conflicts, core anxieties, social defences, patterns of relationships and collaboration) influence task performance (Peltier, 2001).

$>$ It focuses on the exploration of how unwanted feelings and experiences are split off and projected onto particular parts, such as the leader who may have the valance to receive and carry the specific projections and contain them on behalf of the system (Klein, 1975).

Awareness is created of how these introjective/projective identification and process roles are different from their formally sanctioned roles (Obholzer and Roberts, 1994).

It also involves investigating and exploring how symbols are used in the splitting off of parts of the leader. If one part of the leader is used to carry a preferred symbol in this manner, it implies that the other is not interacting with the leader as a total person (Wells, 1980). To facilitate this work in coaching, the authors designed the CIBART consulting model (Cilliers and Koortzen, 2005), which consultants typically use to work with the leader's anxieties and confusion about a number of dynamic behavioural aspects (Koortzen and Cilliers, 2002). The model consists of six interrelated constructs and assists consultants in exploring intrapersonal, interpersonal and inter-group conflicts. The constructs are conflict, identity, boundary, authorisation, role and task. These can be described as follows:

- Conflict refers to splits experienced within the self, between the self and others, inside groups and between groups.

- Identity refers to the realisation of what the individual leader stands for and what lies within one's own boundary.

- Boundary refers to the line and/or space between parts of the system (the individual, the interpersonal relationship as well as the group of individuals).

- Authorisation refers to the positive energy granted to the individual from above, from below as well as from within (the individual himself or herself).

- Role refers to the position the individual or leader takes up which could be based on the normative (the job content), the experiential (the individual leader's own 
- experience of how he or she is performing tasks) or the phenomenal (others' experiences of how the individual leader is taking up the role). Symbolic roles may originate in others' view of the leader; these roles are then projected onto and into the leader.

- Task refers to the building blocks of the role and includes what the individual does hourly, daily or monthly.

During coaching, all of the above are applicable. In this research, the focus was primarily on the role of the leader and the confusion being projected onto and into him or her from the outside.

\section{Psychodynamic processes, role confusion and developing symbolic roles}

This article explores the concept of 'taking up a role and managing oneself in a role'. To take up an organisational or team role implies uncertainty and risk (Czander, 1993; Hirschhorn, 1993; Lawrence, 1999). Anxiety is not simply rooted in a person's internal voices or private preoccupations, but reflects real threats to professional identity. If the individual's anxiety is too great or too difficult to bear, the person may escape by stepping out of role. Anxiety is transformed along a chain of interactions through the psychological processes of introjection and projection. Psychological violence happens inside the individual as a result of the interplay between anxiety caused by real uncertainty and anxiety created by threatening voices within. These mostly parental voices punish the individual and, paradoxically, the individual can feel bad even before he or she has failed in reality. This anxiety chain leads people to violate boundaries and people. When anxiety mobilises behaviour, the individual, at times, experiences other people not as they are, but as the person needs them to be, so that the other person can play a role in the individual's internal drama (Lawrence, 1999). In this regard, consultants often assist leaders and managers in taking up and staying in role; they also make the team aware of unconscious motives and attempts to manipulate the leader out of role or to de-authorise the leader. This may be detrimental to the functioning of the team. The following systems-psychodynamic processes are found to explain how leaders develop or receive these roles (Colman and Geller, 1985; Klein, 1975; Menzies, 1993):

- The valence to receive and respond to specific projections can be described as a predisposition to react and identify with certain feelings. People with a strong valence for aggression, for example, may very easily pick up on the aggression of others and act on or ventilate the feelings on their behalf. Similarly, leaders may pick up on the feelings of followers and start carrying these for the team. It seems that this may often lead to behavioural changes and 'out of role behaviour'. An example of this may be a female 
leader with the valence for picking up the insecurities of followers and taking up a 'mother/nurturing' role.

- Introjection and introjected identification refers to the absorption of the external world in the self. This results in external events being perceived as own psychological processes. This process involves incorporating and internalising threats from the outside that can potentially cause anxiety by infolding them into the internal world of the subject, where they can be neutralised or alleviated. More specifically, introjection means incorporating attributes, attitudes or qualities of an absent person of high significance (e.g. an absent working mother or a recently deceased relative) into oneself. Similarly, leaders may react to the absence of an executive by exhibiting some of the person's behaviour or even taking up their role.

- Projection refers to the defence mechanism according to which a person (or team) ascribes certain unacceptable characteristics about himself or herself to another person. This is done in an unconscious way and leaders may get 'dumped' on in this way.

- Projective identification occurs when the leader identifies with whatever symbolic roles have been projected onto him or her. The person then starts acting in that specific way. This process explains how certain symbolic roles are given to leaders by others.

- Narcissistic defences refer to a denial of the external reality; the external reality is grossly reshaped to suit inner needs. Leaders with this kind of defence may voluntarily take up certain symbolic roles when these offer the needed status and prestige.

These behaviours are found to create anxiety and confusion in and for the leader to such an extent that he or she becomes incompetent even against clear evidence of knowledge, skills and a positive attitude. They also seem to end up representing a certain symbol in the group or actively play a symbolic role. To study this, the researchers used the following research design.

\section{Research approach}

A qualitative, explorative, social phenomenological study was conducted in an attempt to identify, analyse, describe and determine the impact of symbolic roles on leaders.

\section{Research methodology}

Nine consulting psychologists working from a systems-psychodynamic stance were selected as research participants. A 90-minute focus group was conducted during which the participants were asked the following question: 'In your experience, which symbolic roles do leaders take up or are given in teams and what is the impact of these roles on their 
functioning?' The data were analysed by means of content analyses and the systemspsychodynamic interpretive stance was used to formulate the hypotheses.

\section{Findings}

During the focus group, the members spontaneously started speaking about leaders using object relations terms (Klein, 1975) based on the diversity dimensions of race (black and white), gender (male and female) and their different configurations so as to form six leader types. Table 1 contains the symbols and their behavioural consequences connected to the primary diversity dimensions of gender and race.

\section{Table 1: Symbolic roles of leaders and behavioural consequences}

\begin{tabular}{|c|c|c|}
\hline $\begin{array}{l}\text { LEADER } \\
\text { TYPES }\end{array}$ & SYMBOLIC ROLES & BEHAVIOURAL IMPACT \\
\hline $\begin{array}{l}\text { MALE } \\
\text { LEADER }\end{array}$ & $\begin{array}{l}\text { - Father figure } \\
\text { - Messiah } \\
\text { - Thinker } \\
\text { - Hunter } \\
\text { - Object of evil/devil }\end{array}$ & $\begin{array}{l}\text { - Boxed in; followers act like children and deny } \\
\text { the leader his female aspects, such as caring/ } \\
\text { containing - these are then delegated to } \\
\text { females in the system; compete with the } \\
\text { leader to work him out } \\
\text { - The idealised one; to be crucified/disposed of } \\
\text { later } \\
\text { - Deny him his feeling capacity } \\
\text { - Depend on the leader; become passive, } \\
\text { directionless } \\
\text { - Becomes a tyrant, bully }\end{array}$ \\
\hline $\begin{array}{l}\text { BLACK } \\
\text { MALE } \\
\text { LEADER }\end{array}$ & $\begin{array}{l}\text { - Carrier of newness } \\
\text { - Just an AA candidate } \\
\text { - Object of jealousy/envy } \\
\text { from white males } \\
\text { - Privileged one: From } \\
\text { 'garden boy to } \\
\text { president' (Mandela) }\end{array}$ & $\begin{array}{l}\text { - Carries the hope for the future; is forgiven for } \\
\text { the past; forget that he may also have his own } \\
\text { issues to cope with } \\
\text { - Tolerated for political reasons and not for his } \\
\text { own worth; guilt Is off-loaded onto him } \\
\text { - Different unconscious collusions to } \\
\text { disempower him: opposition, belittlement, } \\
\text { non-support, passive aggression } \\
\text { - Do not know where to place him socially or } \\
\text { how to relate to him }\end{array}$ \\
\hline $\begin{array}{l}\text { WHITE } \\
\text { MALE } \\
\text { LEADER }\end{array}$ & $\begin{array}{l}\text { Representative of the } \\
\text { old style/values }\end{array}$ & $\begin{array}{l}\text { - Put under pressure; irrelevant; disempowered, } \\
\text { denigrated; accepted that he will not adapt to } \\
\text { newness; he is watched to not repeat the past } \\
\text { - Needed for his expertise and hated for the }\end{array}$ \\
\hline
\end{tabular}




\begin{tabular}{|c|c|c|}
\hline & $\begin{array}{l}\text { - A love/hate object } \\
\text { - The competent one } \\
\text { - Narcissistic leader }\end{array}$ & $\begin{array}{l}\text { - denigration he represents; inputs, even his } \\
\text { good works, are minimised } \\
\text { - Seen as competent - something the new } \\
\text { 'inpower generation' does not have } \\
\text { - Experiences narcissistic injury; feels } \\
\text { overwhelmed and blames others for not } \\
\text { working; takes on too much responsibility; } \\
\text { does the work on his own; micro manages; } \\
\text { loses vision/perspective; becomes prescriptive/ } \\
\text { instructional/moralising/rude }\end{array}$ \\
\hline $\begin{array}{l}\text { FEMALE } \\
\text { LEADER }\end{array}$ & $\begin{array}{l}\text { - Mother } \\
\text { - Container/womb } \\
\text { - Mother Teresa/Florence } \\
\text { - Nightingale } \\
\text { - Organiser } \\
\text { - Multiskilling expert }\end{array}$ & $\begin{array}{l}\text { - Denies maleness/rational thinking, discipline } \\
\text { - } \text { - Takperiences strong feelings for followers } \\
\text { carries the hope } \\
\text { - Gets caught up in maintenance; clerical; no } \\
\text { capacity for higher-order functions, such as } \\
\text { strategic thinking, understanding dynamics, } \\
\text { complexity } \\
\text { - Overloaded; easily burnt-out }\end{array}$ \\
\hline $\begin{array}{l}\text { BLACK } \\
\text { FEMALE } \\
\text { LEADER }\end{array}$ & $\begin{array}{l}\text { - Nanny/substitute } \\
\text { mother } \\
\text { - Ally } \\
\text { - Winnie Mandela }\end{array}$ & $\begin{array}{l}\text { - Servant; cleans up; picks up the pieces } \\
\text { - Used by white males to build relationships } \\
\text { with black males } \\
\text { Anarchist; detached from the system; feared, } \\
\text { becomes very powerful and then loses power; } \\
\text { has little longevity (succession influence) }\end{array}$ \\
\hline $\begin{array}{l}\text { WHITE } \\
\text { FEMALE } \\
\text { LEADER }\end{array}$ & $\begin{array}{l}\text { - The lesser one - not } \\
\text { good enough } \\
\text { - Ally } \\
\text { - More acceptable white } \\
\text { representative } \\
\text { - Object of envy }\end{array}$ & $\begin{array}{l}\text { - Not the man the system needs (cultural } \\
\text { stereotypes } \\
\text { - For the black man to build relationships with } \\
\text { white men for power } \\
\text { - Represents all whites; feels used } \\
\text { From white males for having new power; } \\
\text { links up more easily with the new black } \\
\text { power }\end{array}$ \\
\hline
\end{tabular}




\section{Discussion}

The results of this study seem to indicate that leaders are manipulated out of role or are given certain symbolic roles that may have a negative effect on their functioning. The authors find that leaders are unconsciously used by their colleagues and teams to represent specific symbols for the other. These behaviours can at best be explained as the system's unconscious defences against the leaders as an object. In other words, the system is using leaders in their personal capacity as a dumping ground for its own unconscious agendas. These defences influence the leader's task behaviour, performance and feelings of wellbeing, both in a destructive and constructive manner. Our analysis seems to indicate that symbolic roles have an impact on all of the constructs in the CIBART model.

Leaders seem to experience intra-personal conflict as a result of role confusion. This results from their inability to differentiate between legitimate and symbolic roles. They may struggle with understanding how they have ended up in the symbolic role and may even feel surprised at how their behaviour has changed over time. The intensity and weight of others' feelings (love and hate), expectations and de-authorisation may be just too much to carry in the long run, which results in self-doubt, anger and frustration. Anger directed at the self may also follow once they realise how they have allowed themselves to be used in these roles. They may even feel that they have 'lost' themselves in the process and are contaminated by all the outside influences. Interpersonal conflict can result from overstepping the boundaries of the given role, becoming too powerful, not playing the role according to the expectations of the team, and attempting to change, redefine or relinquish the role. Boundaries, which include roles, contain anxiety and most employees would prefer little or no change to these boundaries. Team members may, therefore, not allow leaders to change their symbolic roles at will, especially if the roles played by the leaders are containing and nurturing. Leaders who have been typecast as privileged, evil or not good enough may find it particularly difficult when trying to change others' perceptions of themselves or change their roles.

Identity conflicts also seem to result from symbolic roles. Leaders may end up in symbolic roles with associated values that are not congruent with their own. Their personal values may even change as a result of symbolic roles. They may identify with the role to such an extent that they become what the team wants them to be. This may result in intra-psychic conflict, which may include shame and guilt. Being stuck in a symbolic role may also result in leaders feeling devalued when not offered the opportunity to show all sides of themselves. 
Although boundaries are mostly functional, the boundaries of symbolic roles can, however, be rather restrictive. Employees have clear expectations of how leaders in specific roles should act. Attempts to cross these symbolic role boundaries may be met with a great deal of resistance by others and interpersonal conflict may result from this. Changing or relinquishing a symbolic role may create anxiety in a system and the leader's behaviour may be interpreted as aggressive or hostile. In terms of authorisation, it seems that leaders may initially feel flattered by some of the symbolic roles which they have been required"to take on. They may experience the role very positively and feel authorised by the support of the team. Once, however, they become aware of the seduction and get 'killed off', they temporarily lose most of the role power and have to rely on personal power to overcome the crisis. The restrictions of some of these symbolic roles may also limit their authority. They may feel boxed in and unable to use their personal power in the role. Many leaders have reported feeling de-authorised in symbolic roles as well as being unable to renegotiate the role. Female leaders have also reported feelings of being overwhelmed by the dependency of others when they find themselves in nurturing roles. What started off as a positive experience may become a burden and this type of symbolic role may even strip them of their legitimate leadership authority.

A great deal of conflict seems to exist between the normative, the experiential and the phenomenal roles when leaders represent certain symbols. Normatively, they may have a clear understanding of the job content and experientially, they may have the perception that they are operating according to the prescriptions of the job. Phenomenally, however, the role may be contaminated by the perceptions and expectations of and feedback from others. The role the group expects the leader to play may be different from the job description. What they end up doing on a day-to-day basis is, therefore, somewhat removed from the normative job content. This is often the result of trying to satisfy the needs of others in the system and of getting stuck in the limiting boundaries of the symbolic role. Incongruence between the normative, experiential and phenomenal roles creates anxiety for leaders and they may even end up being 'off task' as a result of this. This role confusion leads to task confusion. It is evident from the analysis that leaders may become involved in a number of anti-task activities when they are confused about their roles. These include emotional, ally, containing, representation, window dressing, nurturing, aggressor, carrier of evil, carrier of competence and substitution tasks. These anti-tasks clearly remove them from the real task, which ultimately results in de-authorisation. Although awareness of the above behavioural dynamics falls outside of the traditional coaching literature and practice, it is our experience that the exploration of these defences is helping leaders to understand the deeper psychological dynamics of their relationships and their own role in them. We also believe that making leaders aware of these symbolic roles and exploring the impact of these on their functioning may assist them in redefining their roles and tasks, re-authorising them and reducing the role anxiety they may experience. 


\section{REFERENCES}

Bion, W.R. 1961. Experiences in groups. London: Tavistock Publications. ---. 1970. Attention and interpretation. London: Tavistock Publications.

Cilliers, F. and Koortzen, P. 2005. Working with conflict in teams: The CIBART model. $H R$ Future, October: 51-52.

Clutterbuck, D. 2003. Coaching and mentoring at the top. Management Today 19(5):38-40.

Colman, A.D. and Bexton, W.H. 1975. Group relations reader 1. Jupiter: The AK Rice Institute.

Colman, A.D. and Geller, M.H. 1985. Group Relations Reader 2. Jupiter: The A.K. Rice Institute.

Czandcr, W.M. 1993. The psychodynamics of work and organizations. New York: Guilford Press.

French, R. and Vince, R. 1999. Group relations, management, and organization. New York: Oxford University Press.

Garman, A.N., Whiston, D.L. and Zlatoper, K.W. 2000. Media perceptions of executive coaching and formal preparation of coaches. Consulting Psychology? Journal: Practice and Research 52(3): 201-205.

Goldsmith, M., Lyons, L. and Freas, A. 2000. Coaching for leadership: How the world's greatest coaches help leaders learn. San Francisco: Jossey-Bass.

Gould, L.J., Stapley, L.F. and Stein, M. 2001. The systems psychodynamics of organisations. London: Kamac.

Hall L.M. and Duval, M. 2004. Neurosemantic coaching. HR Future, January: 4-7.

Hillary, D. 2003. Executive coaching. HR Future, October: 10-11.

Hirschhom, L. 1993. The workplace within: Psychodynamics of organisational life. Cambridge: MIT Press.

Hufiïngton, C., Armstrong. A. Halton, W., Hoyle, L. and Pooley, J. 2004. Working below the surface: The emotional life of contemporary organisations. London: Kamac. 
Kilburg, R.R. 2000. Executive coaching: Developing managerial wisdom in a world of chaos. Washington: APA.

King, P. and Eaton, J. 1999. Coaching for results. Industrial and Commercial Training 31(4): 145-148.

Klein, M. 1975. Envy and gratitude and other essays 1946-1963. London: Hogarth Press.

Koortzen, P. and Cilliers, F. 2002. The psychoanalytical approach to team development. In R.L. Lowman (ed.). Handbook of organizational consulting psychology. San Francisco: Jossey-Bass.

Lawrence, W.G, Bain, A. and Gould, L. 1996. The fifth basic assumption. London: Occasional paper.

Lawrence, W.G. 1999. Exploring individual and organisational boundaries: A Tavistock open systems approach. London: Kamac.

Lowman, R.L. 2002. The handbook of organizational consulting psychology. San Francisco: Jossey-Bass.

Menses, I.E.P. 1993. The functioning of social systems as a defence against anxiety. London: Tavistock Institute of Human Relations.

Meyer, M. and Fourie, L. 2004. Mentoring and coaching: Tools and techniques for implementation. Randburg: Knowres.

Miller, E.J. 1976. Task and organisation. New York: Wiley. --- 1993. From dependency to autonomy: Studies in organization and change. London: Free Association Books.

Neumann, I.E., Kellner, K. and Dawson-Shepherd, A. 1997. Developing organisational consultancy. Oxford: Routledge.

Obholzer, A. and Roberts, V.Z. 1994. The unconscious at work. Oxford: Routledge.

Peltier, B. 2001. The psychology/ of executive coaching: Theory and application. New York: Brunner-Routledge.

Schein, E. 2005. Course in career and executive coaching. Pretoria: Unisa. 
Sperry, L. 2004. Executive coaching: The essential guide for mental health professionals. New York: Brunner-Routledge.

Tonsing, T. 2003. Coaching skills training. HR Future, April: 26-29.

Turquet, P.M. 1974. Leadership: The individual in the group. In G.S. Gibbard, J.J. Hartman and R.D. Mann (eds). Analysis of groups. San Francisco: Jossey-Bass.

Wells, L. 1980. The group-as-a-whole: A systemic socio-analytical perspective on interpersonal and group relations. In C.P. Alderfer and C.L. Cooper (eds). Advances in experiential social processes 2: 165-198. 